\title{
КРИЗА МЕДИЈСКЕ КОМУНИКАЦИЈЕ: На трагу рукописа Медиографија Јасне Јанићијевић
}

\begin{abstract}
Пратећи траг необјављеног рукописа под називом Медиографија, у којем је Јасна Јанићијевић одредила функције и садржаје масовних медија, и њихова тематска ограничења, дисфункције попут оних узрокованих наркотицима, репродуктивност, тенденциозност, анти/интелектуализам, као конформизам, аутор овог текста указује на фаталне (штетне) последице савремене крисе која се тиче медијске комуникације. Имајћи на уму идеје Јасне Јанићијевић, аутор нарочито анализира значај образовање за медијску сферу у којој би слобода, одговорност, контрола као и само-контрола представљале константе.
\end{abstract} вање

Кључне речи: култура, култура медија, комуникација, криза, образо-

Кад је темељну цивилизацију књиіе у великој мери заменила експанзивна циивилизащија слике променио се стил људског комуницирања. Масовни медији су већ одиграли пресудну улогу не само у напуштању традиционалне културе него и у стварању њене аудио-визуелне наследнице. Ова новонастајућа култура све више постаје основа културе нашег времена. Створена посредством техничког ума, она оставља за собом принцип стваралачког индивидуалитета и успоставља колективни доживљај света и нове вредности. Све што се тиче духа и креативности, што тражи уточиште у творачкој слободи и тајновитој истини, удомљује се у књигама. Данас је књига на раскршћу. Нашла се у близини моћних електронских медија и нових технологија. Ипак, нова средства комуникације нису »убила« књигу и поред тога што се већ сада променио карактер комуникације са вредностима културе. Тешко је и поверовати да ће књигу било што друго и у будућно- 
сти моћи заменити без остатка, јер је она атрибут човекове слободе, свести и сазнања. У њој је сабрано највредније искуство многих поколења и човекова творачка меморија. Она ће свакако усавршавати и своје комуникативне могућности и свој стваралачки утицај. У размени духа, мисли и идеја - књига остаје незамјењива и поред тога што је у савремености изгубила своја традиционална упоришта. Зато се и може рећи да без чаробнице - књиге нема целовитијег откривања човекове суштине и тоталитета његовог постојања. Није најсрећнија околност то што живимо у времену у коме је најзаступљенији Музилов »човек без својстава« или менталитет у коме би у сваком плебисциту бечка оперета победила Моцарй $а$, како је већ запажено. Зато су у праву сви они који заступају мишљење да је одбрана књиге чин слободе и претпоставка да се искаже интегритет умности. Савремени свет можда понекад и запоставља књигу, али ће тешко пристати да остане без ње. Био би то готово варварски чин. У књизи су садржани најпоузданији трезори вредности и будућност памћења.

Култура и комуникација прожимају се у свакој компоненти свога бивствовања. У таквом су односу да се непрестано условљавају и успостављају најприснију узајамност. Комуникација као важна категорија постојања и културе представља «путовање» до себе и до света. Она повезује и спаја. Преко ње се врши размена искуства од мишљења до делања. Као йроцес и као иниееракиија, комуникација успоставља и нову лествицу вредности. То је уверљиво показала и Јасна Јанићијевић у својој бриљантној студији Комуникација и кулширра. У њој је ауторка остварила тежиште на семиотичком аспекту комуникације. Свакако, и тај аспект у проучавању комуникације само је део научног и филозофског промишљања комуникације и модерних комуникацијских процеса. И што култура више означава целину човекових свеокупних могућности, тоталитет и вредности живота, то су присутнији потенцијали људског комуницирања. Човекова комуникативна природа долази нарочито до изражаја у реализовању културе као стила живота и као умног збивања у човеку. Њена неприлагодљивост за креативну и критичку комуникацију, као форму индивидуалитета, данас је више је него очигледна.

То ће уверљиво показати и Јасна Јанићијевић у свом необјављеном спису Meguоїрафија у коме је приступила продубљеном проуча- 
вању медија и образовању у сфери масовних комуникација. У самом уводу, она је записала: Меgиоірафија йоgразумева gа ћемо се бавииии меgијима ойисујући их, ире свеі̄а, као друшйвене и кулииурне йојаве, јер нас сваки оg меgија на различите начине суочава са самим собом као gрушиввеним бићима. И иииме не само gа обликује наше зајеgничке

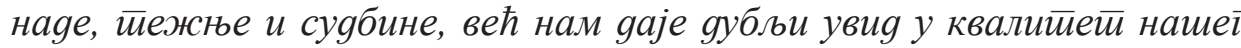
живой $а$. И кад је идентификовала функције и ефекте масовних медија, кад је проучавала њихове садржаје, кад је трагала за њиховом слободом, одговорношћу, контролом и самоконтролом никада нису изостајали увиди у индивидуалне, друштвене, културне, политичке и економске последице. Њено настојање да скрене пажњу на цивилизацијску неопходност да се успостави образовање за медије у свим формама живота од великог је значају за стратегију неминовних промена у медијској сфери.

Чини се да нико у нашој средини као Јасна Јанићијевић није био спреман да истражује корелацију између масовног друштва, масовне културе и масовних комуникација. Доиста, она понајвише застаје пред медијским садржајима, комерцијалним и популарним, да би аргументовано показала њихова непревладана $\overline{и е м а и ̆ с к а ~ о і р а н и ч е њ а, ~ р е и ̆ р о-~}$

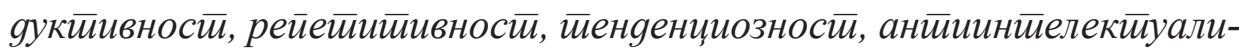
зам и комформизам. У власти комерцијалне логике, комерцијалног медијског тржишта и великих корпорација, медијски садржаји следе циљеве профита. Поред ове и овакве доминантне појаве и тенденције у успону, Јасна Јанићијећ показује да образована и имућна мањина не упада у клопку “семиотичке” неједнакости која предодређенана за преовлађујућу већину.

У тумачењу друштвеног и културног утицаја медија, Јасна Јанићијевић придаје велики значај медијској одговорности, контроли и самоконтроли. Поред тога што протагонисти медија преузимају одговорност да реализују своје цивилизацијске обавезе, нормално је да прихвате и медијску етику, примерену плуралистичким друштвима, са незаобилазним питањима истине и правичности. По мишљењу ове наше ауторке услови под којима медији функционишу далеко су од йлайоновских ияеала јер су у великој мери детермунусани околностима, местом и временом. Упркос неповољним цивилизацијским и друштвеним околностима, као институције од великог друштвеног 
значаја обавезне су да йонуgе релайивно уравноиежено и йошиено ілеgишие друшиива коме служе и које одражавају. Залажући се за балансирану и истинољубуву слику друштва, у интересу мањине и већине, Јасна Јанићијевић истиче да медији не би смели да подлежу ономе што публика жели и очекује. Да би деловали слободно и у интересу јавности, власти не би смела ни да их цензуришу, ни ограничавају, ни контролишу, али би било природно очекивати да у друштву створе атмосферу за слободу медијског испољавања. У ствари, ауторка се залаже за остваривање демократске филозофије комуникације, у чијим би темељима пулсирала слобода и одговорност, као алтернативе и репресивној контроли и технолошком детерминизму као поствареном посредништву. То био био начин да се масовни медији користе за ширење културног и образовног хоризонта, што би било неспојиво са било којом формом вулгаризавије у стварању и тумачењу вредности, а посебно вредности човековог постојања. Тако би се етички идеал нашао у пуној сагласности са духом просвећивања. До тога је могуће стићи само у атмосфери индивидуалне одговорности без политичког притиска и било каквог условљавања у коме би се доводио у питање и професионализам и морални дигнитет твораца медијске комуникације.

Јасна Јанићијевић посебну пажњу посвећује идејама Дагласа Келнера о медијској култури која у обличју нейризнайе йеgаīoīuје васпитава публику у свему што чини, усмерава је како да се понаша и како да мисли. На тај начин, она делује и на формирање креативних потенцијала личности у њиховој свакодневници, у којој доиста долази истовремено и до поништавања и до подстицања њихове креативности. Уз медијску писменост и оспособљавање да се мисли критички могуће је радити на индивидуалном идентитету и креативној самопотврди личности. То значи успротивити се манипулативној доминацији медијске културе. Владајућа култура данас, која је у великој мери заменила облике утицајне високе и традиционалне културе, пристиже са неопходношћу успостављања новог типа медијске писмености. То је значајно посебно стога што је медијска култура веома утицајна у процесу социјализације и обликовања нових модела идентификације. Та култура намеће вредности, моду, укус,стил понашања и начин мишљења.

У средиште своје анализе масовних медија Јасна Јанићијевић ставља теорије Дагласа Келнера да би показала у каквом су односу 
реалност и медијска култура. У опсежном делу Меgијска култура, Даглас Келнер (Douglas Kellner) не користи термине масовна кулйура и йоиуларна кулйура јер сматра да су они идеолошког порекла и неизвесног теоријског исходишта. У својим истраживањима, он искључиво користи појам меgијска куличура. Келнер је уверљиво показао да је доминантан и незаобилазан облик савремене културе заправо медијска култура. На његова културолошка истраживања посебно је утицала франкфурска филозофска школа, британске студије културе и постмодернистичке теорије. Што се тиче франкфуртске школе, њему је била неприхватљива крута подела на класичну и нижу културу, јер су, на тај начин, одбациване као идеологија сви облици популарне и масовне културе. Зато су му биле прихватљивије студије културе, утолико пре што су се у њима ове разлике брисале. У студијама културе друштвено - историјски контекст незаобилазан је. У тумачењу културе полазило се од друштвене, економске и политичке стварности. Међутим, Дагласу Келнеру неприхватљива је постмодерна идеја о смрти херменеутике и настојање да се опише површина и форма културних творевина. Он не пристаје на такву методологију. Оцењује је као ограничену и једнострану, тим више што је усмерена превасходно на форму и имиџ као средиште спектакла.

Овај теоретичар медијске културе упорно трага за значењем и смислом медијске комуникације. Њему је потпуно неприхватљиво постмодернистичко становиште »да је телевизија обична бука у постмодернистичкој екстази, чиста имплозија, црна рупа у којој сва значења и поруке нестају у вртлогу и калеидоскопу радикалне семијургије, непрестаног расипања слика и информација до тачке потпуног засићења, инерције и апатије«. И кад се прихвати да је телевизија $\bar{u} y$ сиииюа йовшних слика, у праву је Келнер кад тврди да се она може гледати на различите начине и да јој се као важном делу медијске културе не може оспорити утицај на обликовање мишљена и понашања савременика. Наднесена над светом као над шареним ћилимом визуелног, опчињена сопственим светлуцањем, телевизија и не слути да се претворила у убицу човековог времена. Навикнута на дух површног живљења, вична умртвљивању животних околности, телевизија, у ствари, одбија да стварност види онаквом каква јесте. Кад привид и виртуелно доминирају стварност је скрајнута. Ње више нема у изворном обличју. 
Широк захват видног поља медијске културе у свакодневљу утиче на то да се обезбеђују процеси идентификовања са владајућом идеологијом и постојећим системом вредности. И у анализама филмова Роки и Рамбо, реп музике или Мадоне, криминалистичких серија или рекламе, вести или дебата у медијима, аутор ће обзнанити не само механизме доминације и манипулације него и идеолошке и политичке утицаје. То важи и за приказ глобалних медијских догађаја као што је Заливски рат. Да би се утемељила у истраживања студија културе, медијска култура - са сликама,симболима, митовима и веровањима - не пропушта владајућу политичку идеологију, не пропушта конзервативистичка, либералистичка и радикалистичка гледишта. Келнер је покушао да са тих становишта протумачи чак и симболичке форме медијске културе. Да би извршио ияеолошку крииикку филма Рамбо, аутору није било довољно да осветли милитаризам и импе-

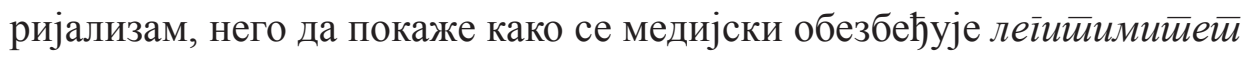
инйервенцијама. Послије пораза у Вијетнаму и вијейнамскої синяромa, у време Реганове владавине и интервенционистичке спољне политике, помоћу лика ратног хероја, непобедивог ратника, успоставља се »хегемонија« политиче идеологије. У контракултурној, маскулинистичкој и десничарској мотивацији, Рамбо као оличење инguвиgуалисииччкої хероизма и готово мийскоі̄ хероја изразит је представник медијске културе. Он се поистовећивао са смрйоносном милийари-

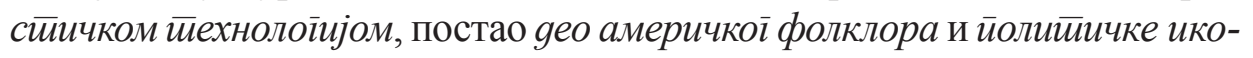
ноїрафије која је требало да поништи сећање на ратно губитништво у Вијетнаму. Видели смо и тамо и овде да ниједна освета не може умаћи ирационалности и мржњи.

Аутор дела Меgијска куличура показује како и готово безвредни холивудски филмови крче путеве америчкој спољној политици. То се дешавало за време владавине и Регана и Буша, старијег. Уместо комунистичког непријатеља »осмишљен« је арапски непријатељ. Нови непријатељи толико су демонизовани да личе на нељудска бића, на мрачне садисте и окореле злочинце. Створен је антиарапски стереотип. У милитаристичкој медијској култури направљена је манихејска подела на gобре и рђаве момке. Што је најгоре, направљен је непремостиви јаз између хуманих, рационалних, рафинираних, иерсонализованих Американаца и варварских, ирационалних, gеиеронализованих 
Арай . Тако је медијска пропаганда извршила припрему за Заливски рат. И поред тога што је у Сједињеним Државама постојало и антиратно расположење, медији су у толико давали подршку рату да је испадало да Заливски рат високо рангиран у скали популарности и да се у нацији дешавају оріије йайриойизма. Симулирајућом реториком, преваром и манипулацијом припремала се, у ствари, јавна изведба ратног спектакла у стилу спортске утакмице. Победник је био унапред познат. Жан Бодријар (Baudrillard) je, као аналиииччар ириви$g a$, како је себе ближе одредио, Заливски рат видео као симулакрум и симулацију догађаја или хиперреализам. По његовом мишљењу, овај рат је био само медијски спектакл и ништа друго. Он је сматрао да медији стварају догађаје. У његовом виђењу, то је значило да је виртуелна стварност произведена у медијима, у ствари, потиснула и истину и стварност и смисао. Ако је виртуализација поништила стварност, онда је убила и историју јер је постојала само илузија историје. (Baudrillard J., L'illusion de la fin). Дакле, у питању је не само “деструкција” него елиминација реалности.

У делу Кулииура и имиеријализам, које је објављено 1994. године, у Њујорку, Едвард Саид оштро критикује амерички меgијски имиееријализам. Пре суровог покоравања Ирака, насилничка медијска пропаганда била је изгубила сваку меру и сваки обзир. Аналитичари тврде да је Ирак сматран за једну од најстабилнијх земаља Блиског истока, док је Садам био у милости великих сила. Невоље ирачке настају кад је извшен напад на Кувајт 1990. године. Тада је и међународна коалиција узвратила нападом на Ирак. Дошло је Првог заливског рата. Све је то било мутно и крваво, али и са лажном сликом и преваром у медијском огледалу. Медијско огледало било је усликано као спектакл лажи и преваре. У разарању Ирака тешко је не видети идолатрију силе, силништво и насиље, али и разлоге уништења разума и одговорности уз активно присуство спектакла мас-медија. Таквим историјским исходиштима, удео милитаризоване медијске културе био је драстичан. И катастрофалан. А споран ће бити увек њен утицај кад изостану могућности пацификације и суочавања са истином и у јавности и у медијима.

Виртуелна стварност у медијској сфери била је подстицајна истраживачка преокупација Јасне Јанићијевић. Уверена да је та ствар- 
ност оно ший jе og ње сииворимо упућује на мишљење да је она вредносно неутрална јер није ни gобра ни лоша а њене границе и њена ограничења требало би тражити у човековој машти. А то да ли ће се виртуелна стварност реализовати као свакодневље које узима под

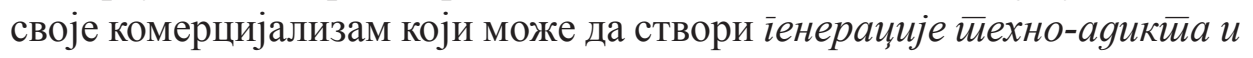
соииойай на стварност препознаје као темељна претпоставка савремене комуникације, њених предности и њених слабости.

Онтолошки и феноменолошки поглед на медије не може избећи и категорију виртуелног ни категорију привида. А то да свет привида иостиаје акйуелан, са онтичког и онтолошког становишта уверљиво је показала Дивна Вуксановић у студији Филозофија меgија. А данас, кад се говори о привиду као темељу спектакла, има се утисак да су заборављене искључиве и нетолерантне расправе о масовној култури. Оне су увек садржале за и против. У неприхватању ове културе био је присутан традиционални критеријум вредновања, јучерашњи укус и инерција менталних процеса. Масовна култура је, у међувремену, постала реалност нашег времена, доминантан део његовог свакодневља, незаобилазна вредност начина живота. Она је, веома агресивно, без изгледа на повлачење, заузела огромни друштвени простор и за релативно кратко време успела да овлада масама и њиховим доживљајним светом. У томе је успела, ако ни због чега другог, оно стога што је наметнута као »најдемоктатскија« култура до данашњих дана. Ни то није био довољан разлог да теоретичари, приврженици традиционане и елитне културе, не буду против ње чак и пре него што су схватили шта она, доиста, јесте и шта може бити. И што је најгоре, у политичком смислу, сматрало се да она помаже успостављању тоталитарних система. Масовна култура, очигледно, неоправдано је оспоравана у име елитне и традиционалне културе, али можда још више демагошки и некритички прихватана. Она се, међутим, није могла негирати већ и због тога што је постала део прихваћеног свакодневља и владајућег обрасца живљења. У вредновању масовне културе и даље је неизоставан одговор на питање - да ли она проширује или сужава човекову креативност, да ли потпомаже или спутава људску слободу? Та питања се могу поставити и за ововремену доминацију спектакла, тему сваког културолога, па и Јасне Јанићијевић. 
То је и разлог осврта на феномен спектакла. У тумачењу дела Друшитво сиекииакла (The Society of the Spectacle), увелико се доказивало да су идеје Ги Дебора (Guy Debord) о карактеру и досегу спектакла биле од знатног утицаја на разумевање делатности које су обухваћене категоријом слике, вида и визуелних средстава комуникације. Његово становиште о томе да је спектакл наследник свих слабости западног „пројекта“ упућује на мисао да људима управља капитал. Дебор је крајње сажето дефинисао спектакл као кайитиал у сииуйғу акумулаuије у којем он йосйаје слика. Доминација видног поља и спектакл као роба обзнањују спољашност и форме привида. О њима Дебор говори као о орїанизованом йривияу са неизбежном неїацијом животиа. Ако сииварносии израња из сиекйакла као видљиве негације живота, како то тврди Ги Дебор, онда друштво спектакла постаје темељ и медијске културе и човековог свакодневља. И није то небитна негација живота као непоновљивог и изворног збивања него је она и свеприсурна у својој тоталној и заслепљујућој видљивости.

Деборова истраживања спадају у радикалну неомарксистичкиу мисао 20.века, која се темељила на Марксовом и Лукачевом сазнању, на Марксовој теорији о фетишизму робе и Лукачевој теорији о реификацији. Дебор је сматрао да је сиекйакл најприкладнији израз којим би описао све савремене људске интеракције у друштву јер спектакл „није скуп слика, него друштвени однос између појединаца, посредован сликом“. Анселм Јап/Anselme Jappe/, вероватно најбољи познавалац Деборовог дела, и сам полази од фетиишизма робе да би идентификовао спектакл као „најразвијенији облик друштва заснован на производњи робе и њеном резултату.“ Он сматра да из Деборовог мишљења произилази да је модерни спектакл наследник религијског спектакла. (Jappe. A., A Guide to Guy Debord s Concept of the Spectacle). У сваком случају, Деборова истраживања, ето, трају од шездесетих година прошлог века до данас. После дводеценијске дистанце, он је испољио своју приврженост првобитним поставкама. Готово ништа не додаје почетним тезама, већ само разјашњава концепт иниееірисаной сиекийакла,који упућује на његово свеопште и свеобухватно ширење. Реч је о свеприсутности и моћи спектакла. У периоду од 21 године, од 1967, када је настало његово дело Друшииво сиекииакла до тренутка кад се појавило његов спис Comments on the Society of the 
Spectacle, који је објављен 1988. године и када се очекивала и могућа реинтепретација његових изворних доктрина, он се определио да оспори само йоїрешна тумачења у сфери спектакла. Једно од них је и оно распрострањено мишљење, по коме људи више воле да употребе израз меgији него спектакл. При том, не заборавља да разјасни да су медији само инсиируменй који спектакл користи. Да то није баш тако, показао је Маршал Маклуан у делу Познавање оишишила-човекових ирояужейака. Важан закључак у његовој теорији свакако је тврдња да ойшиилла йреgстиављају йоруку. Он ће се побринути да за овакву тврдњу прибави и најјачу аргументацију, у коју ће укључити природу и форму нових општила и каквоћу чулног доживљавања иоруке. Он ће, на тај начин, атаковати на један аподиктичан и готово усвојен став у науци да су технолошки проналасци вредносно неутрални, то јест да они сами по себи нису ни добри ни рђави, већ да им начин употребе одређује вредност. Такав став Маклуан оцењује као ілас сомнамбулизма. Он ће многим примерима веома ефектно довести у питање овакво гледиште. Зато ће Маклуан и говорити о психичким и друштвеним поремећајима изазваним телевизијском сликом, а не телевизијским програмом. Истраживачи медија, као и Маршал Маклуан, а нарочито Жан Казнев(Jean Cazeneuve), истичу да се савремена култура налази у периоду дубоке култуно-социјалне мутације којој се савременик није прилагодио. Због инерције менталних процеса, по мишљењу Казнева постоје тешкоће у савлађивању аудиовизелног света и изражавњу помоћу нових средстава општења. Зато масовни медији теже да од индивидуе створе једну врсту воајера и, реципрочно, да трансформишу свет у спектакл. Казнев је образложио како човек йрансценguра сопствену реалност у спектакуларну надреалност. (Cazneuve J., Communication de masse et mutations culturelles). Мас-медији су до те мере хомогенизовани и стандардизовани да убрзо добијају карактер стереотипа. Теодор Адорно сматра да телевизија људе још једном чини оним што они јесу. То одговара израженој тенденцији данашњег неолибералног друштва да савременик у својој свести не превазилази себе нити постојеће стање, већ да га непрекидно учвршћује и чак да га, тамо где је угрожено, опет обновља. Тако се и дешава, пише Адорно, да културна индустрија, са телевизијом на челу, уместо да уздиже несвесно до степена свести и тиме измири његову разорну снагу, још 
више редуцира људе на степен несвесног понашања. (Адорно В. Т., Два есеја о йелевизији). Ако је то тако, онда постаје схватљивије распрострањено мишљење да масовни медији, суштински, и не стижу до индивидуа, већ само до масовног аудиторијума.

Није тешко запазити да су се медији за масовно општење битно променили од Фукоовог (Michel Foucault) првобитног концепта Панойшикона, који је „прочитан“ као моћна машина која подједнако умрежује и оне који успостављају моћ и оне над којима се успоставља моћ. Фуко, који је показао игнорантску дистанцу према Деборовој идеји да је модерни спектакл произишао из религије, доказује да је божије око заменила машина која вияи. А кула за посматрање постала је“"прозирна зграда у којој примену моћи може посматрати друштво као целина“. Фуко, као најзагонетнији теоретичар моћи, у формама надгледања и кажњавања, обзнањује механизме потчињавања, класификовања, устаљивања, дресирања, осматрања, кодификовања понашања и оцењивање јединке, али уз њену потпуну видљивост. Тако је модел затворске институције са кониролом gуше настао и пре озваничења затвора као места казне по кривичним законима. (Foucault M., Surveiller et punir: Naissance de la prison). Није случајно, као што је већ примећено, што је Жан Бодријар (Jean Baudrillard). у ствари, Фукоове теорије видео искључиво као метафоре. Под утицајем Ничеа и Батаја, Бодријар ставља у први план своје теорије симболичке размене насупрот утилитаризму капиталистичке продукције и потрошње. У тој супротстављености дошло је суштинског разилажења између модерних и постмодерних друштава. По мишљењу Жана Бодријара, модерна друштва су организована по принципу производње и потрошње док су постмодерна организована по принципу симулације и игре слика и знакова. И зато није необично што се у средишту његове теорије налазе категорије симулације, имплозије и хиперреалности. Садашњи медији и њихове менталне матрице пристижу из света у коме је увелико присутно ишчезавање стварности као вредности, али и нестајање спектакла као паноптичке субјективности и спектакуларности. Он долази до закључка да крај спектакла носи са собом „Урушавање стварности у хиперреализам, превише детаљну репродукцију стварности, највероватније кроз друге репродуктивне медије попут рекламе или фотографије“ (Baudrillard J., L’Échange symbolique 
et la mort). Што је најгоре, у бескрајном копирању истих знакова, у недостатку перспективе, што је већ запажено, нема ни осмишљеног значења постојања. А постојање личи на оно место из Шекспировог Магбета:“Живот је историја коју прича неки идиот, пуна буке и беса, која ништа не значи“. У питању је драстична криза смисла. Савремени човек суочио се са светом без компаса и са свешћу без смисла за смисао. Кад економске вредности имају не само средишну и доминантну улогу него кад потискују и покривају све друге вредности онда се може и догодити да се потрошња не доживљава као средство већ као циљ, а профит као једина вредност. Колико је то апсурно не вреди доказивати. Најгоре је што су поседице далекосежне са становишта развитка људских потенцијала, индивидуалне и друштвене слободе као вредности постојања.

Ту искрсава још један проблем који се везује за пасивног посматрача, о коме расправља Жак Рансијер (Jacques Ranciere) у једном предавању које је насловио Еманцийовани йлеgалащ, а одржао га је у академској четврти у Франкфурту 2004. године. Он сматра да у свим врстама спектакла, у сусрету са колективном публиком, гледалиште показује своју рђаву страну јер постаје пасивно гледалиште. И зато што гледалац поприма статус пуког посматрача, који са дистанце прати спектакл, а он је двоструко споран:““ Прво, посматрање се ставља као супротност знању. Оно значи налазити се испред неке појаве, без познавања услова за производњу те појаве или стварности која стоји иза ње. Друго, посматрање је супротно деловању. Онај ко посматра неки спектакл остаје непокретан у свом седишту, без имало моћи да интервенише. Бити гледалац значи бити пасиван. Гледалац је раздвојен од способности сазнања на исти начин на који је раздвојен од могућности да делује“. Тако размишља Рансијер, који не пристаје на симулакрум спектакла нити на пасивног посматрача јер без његове активности не преостаје му ништа друго него да изгуби себе самог, да остане без властитог бића. То је разлог што ће се залагати за позориште без гледалаца као пасивних посматрача који су ойчињени сликама колективног света који је у несагласности са суштином индивидуалне стварности.

Јасна Јанићијевић у спису Меgиоірафија формулише силовити утицај масовних медија као појаву наркойизирајуће gисфункције јер медијском поплавом корисници медија постају толико пасивни да де- 
лују као да су под наркозом, да су наркотизовани. Та наркотизујућа функција запажена је у неким неразвијеним земљама где се очекивало да ће масовни медији извршити важне промене традиционалне заосталости, али то се није догодило. Тако медији нису битније утицали ни на образовање људи нити на прогрес неразвијених земаља. Што је најгоре, сматра се да медији могу да утичу на појаву деструкције и зла у друштву, да створе пометњу и подстакну велику дезорјентацију у друштву и животном стилу људи. Тако медији могу да скрену пажњу на девијантно и „непримерено“ понашање.

A reality show се истиче по томе што безначајне личности извлачи из потпуне анонимности а тиме прави вредносну конфузију. Да није у питању масовна медијска појава у којој су и пострадали критеријуми о вредностима, али и саме вредности не би јој требало придавати велики значај. То је и разлог што се мора сматрати културолошки релевантном чињеницом. Покушај изумитеља ријалити програма да доминантна визуелна култура успостави равнотежу са реалношћу не делује више као експеримент. Штавише, телевизијски програмери настоје да овај медиски жанр учине толико моћним да постане, бар по утицају, моћнији од реалности. И реалнији од реалности. Ту већ морамо застати и упити се: да ли је то могуће? Гинтер Грас је недавно изјавио да се стварност друштва мери по мери медија. Тако, испада, да стварност лаже ако није по мјери медија. А то што је ријалити шоу овладао широким аудиторијумом не би требало видети као последицу спектакуларних замисли телевизијских програмера. У ловљењу телевизиских душа учествовали су и уловљени, приврженици оваквог медијског умрежавања. Познато је да се посредством мас-медија, овакве персоне припремају за некритичко прихватање свега сто им се намеће. Вероватно их осиромашена перцепција удаљује и од стварности и од властите истине.

Није потребно доказивати да утицаји који се успостављају у домену медија у великој мери зависе и од саме природе медија, али би суштину тог утицаја ваљало тражити на тлу људске психологије, у тоталитету унутрашњег човековог бића. Изгледа да је видљива повезаност између врсие слике која стиже из спољашњег света и њеног понављања у медијској изведби. Свакако, она није без пукотина. Штавише, тешко је стићи макар и до лабаве хомологије. Можда је хомо- 
логија која се успоставља између посматрача и посматраног много извеснија; готово је без пукотина. И кад се покушава проникнути у механизме идентификације и свеприсутне популарности реалне $\overline{\text { e}}$ левизије неопходно је суочити се са заједничким именитељом менталне и психолошке слике телевизијских верника. То значи да слика није само споља него и унутра, у посматрачу. Тако се и догодило да телевизија претвра своје племе у воајере, а свет трансформише у реалност спектакла. Зато су медијски утицаји и њихова перцепција у коеїзистиенцији. То је већ нешто друго од реалне телевизије. Обликовати реалност вештачким путем неизвесно је путовање, готово безизгледно. Непосредност, спонтаност и искреност остају без заштите. Тако, оно што се жели највише досегнути бива највише спорно.Тешко је поверовати да телевизијски програм овог типа може постати поуздан рендген преко којег ћемо “прочитати” природу оних који су се нашли не у кули од слоноваче већ у кули од стакла; у јавној кући без зидова. На то су пристали. Спремност да се подвргну владавини Великог Брата довољно говори о природи оваквог подаништва и оваквих поданика, али о медијској манипулацији.

Јасна Јанићијевић приклања се уверењу да публика што је у више отклону и у активном ставу према убеђењима која долазе из масовних медија биће и више отпорна према медијском убеђивању, утицају или манипулацији. То је свакако пожељна тенденција јер по мишљењу ове ауторке активна публика обезбеђује фиябек за комуникаторе медија а тиме се успоставља интерактиван однос. Тако би требало разумети што нове медијске технологије поседују веће могућности интерактивности. У психолошком смислу, сматра ова ауторка, смањују се раздаљине у свету толико и тако да и свет чини мањим него што јесте. То свакако не значи да је тај свет могуће обујмити погледом нити лишити снага деструктивности а још мање отклонити опасне последице које су увелико на делу.

А кад економске вредности и конзумеризам имају не само средишну и доминантну улогу него кад потискују све неспорне и трајне вредности, онда се може и догодити да се потрошња и неолиберално тржиште и не доживљавају као средство већ као циљ, а профит као једина вредност. Колико је то апсурно не вреди доказивати. Најгоре је што су поседице далекосежне са становишта развитка човекових кре- 
ативних потенцијала. У пуној сагласности са тржиштем либералног капитализма, присуство глобалних медија делује као незаустављива стихија, као неумитна и лагодна диктатура. То је ваљда једина диктатура која се прихвата без отпора. Зато је и лако „умрежити“ пасивне посматраче, такозване „конзументе“. У сваком случају, таква глобализација медија представља велику опасност за активно учешће грађана у друштвеном животу и за њихово непосредно укључивање у живот са смислом.

Контровезно устројство данашњег света донело је нове и готово нерешиве проблеме. Није мала невоља што су све културе постале хибридне и у великој мери немоћне да постану креативна снага отпора глобализацији. А то су процеси који су озбиљно запретили и државним и националним и индивидуалним идентитетима, посебно у земљама транзиције. И у нас надмоћно владају комерцијални медији али и естрадна култура. По емисијама које су се у појавиле у индиго издању и са најприземнијим садржајима постаје јасно да више ништа не може бити у медијској сфери као што је некад било а и што би требало да буде са становишта вредности.

С друге стране, панични страх од нових медија и нових технологија није најбољи савезник разложности и реализму. Њихов упад у свакодневље савременика свакако није наивна околност за обезбеђивање хармоничног стила живљења, као и за рецепцију медијских садржаја и за „интимни сусрет“ утолико пре што се нигде није догодило промовисање медијске писмености нити медијска едукација. Свакако, нема разлога да се посумња у то да медијске и технолошке иновације утичу на човекове креативне способности и да их често блокирају. С обзиром на постварено и драматично присуство технике у савременој цивилизацији, Исидора Секуловић је поодавно скретала пажњу на могућност да се машинизира не само човеков мозак него и његово срце. А ових дана читам преко друштвених мрежа Ајнштајнову изјаву: "Бојим се дана кад ће технологија надрасти међуљудске односе. Свет ће добити генерацију идиота“. Можда се то није још догодило, а може се догодити. Све је у великом убрзању али и у великој неизвесности.

Многи теоретичари културе сматрају да је цивилизација књиге не само уморна него и уморена и поред тога што су у њој ускладиште- 
не највише вредности - слобода, лепота и истина. Међутим, често се заборавља да из њеног кординатног система нема смисла вредновати ни масовне медије ни нове технологије ни чуда савременог света. Шта онда? Социолози, педагози и психолози ће рећи да је неопходно заштитити бар младе људе од медијске зависности, медијске манипулације и безвредних медијских садржаја. То се не може оспоравати али остаје неизвесна способност критике медијске културе и трагање за вредностима и добрим укусом у самим медијима, за њиховим алтернативним и креативним формама. Нема повратка на цивилизацију књиге. Одговор се мора тражити у времену садашњем. Интелектуалци а посебно теоретичари студија културе могли би помоћи да се велика магла у медијима и око њих разагна, бар онолико колико је могуће.

На стање наше медијске сфере од великог је утицаја успон глобалних и комерцијалних медија са неизбежним спектаклом. У сагласности са концептом неолибералног тржишта, уз залепљујући блесак спектакла, присуство глобалних медија делује као опсена, стихија и лагодна диктатура. То је ваљда једина диктатура која је прихваћена без отпора. Не постоје велике тешкоће да се умреже дезорјентисани посматрачи који су се у време екстремне кризе и мука транзиције суочили са хаосом, насиљем и безакоњем. Глобализација медија одвија се уз масовно ширење популарне културе. Тако се у ствари „руше“ националне и државне границе у домену вредности и успостављала репресивна глобализација. То што се у овим медијима фаворизује „лака забава“, насиље и секс који је ближи порнографији него еротици, показује да су они највише усмерени на то да обликују потрошачко друштво и да стварају „конзумента“, а не слободног грађанина. У друштву турбулентне транзиције,какво је наше, у коме доминира естрада, највише имају могућности да опстану тривијалне творевине! Ма колико да је свака тржишно-естрадна мода пролазна као летња киша, она се у друштву кризе, сиромаштва и транзиције може и подуже задржати. Та мода се нажалост непрестано понавља поред осталог и стога што је критика Ахилова пета наше културе. А у нас естрада, популизам и конзумеризам, подилазе елементарној и функционалној неписмености. У сиромашном начину живота, какав је овдашњи, преовлађује стварност без култивисности, поезије и снова. То је увод у 
»јевтиноћу« укуса и »новоконповану« културу беде. Бриге преживљавања неспојиве су са еросом живљења. Са неписменим и полуписменим најлакше се манипулише. Њих је већ фасцинирала ТВ - слика. И спектакл.

\section{Литература}

Адорно, Теодор В. Два есеја о иеелевизији. Летопис Матице српске, Нови Сад 2-3/1966

Baudrillard, Jean. L'Échange symbolique et la mort. Gallimard, Paris, 1976. Baudrillard, Jean. L'illusion de la fin. Gallimard, Paris, 1995 Baudrillard, Jean. Impossible Exchange. Verso, London, 2001 Бењамин, Wалтер. Уз криииику силе. Разлог, Загреб, 1971. Bozovich, Ratko. Play-Fundation of Culture. Universe, New York, 2008. Божовић, Ратко. Рам за слику. Чигоја, Београд, 2010.

Cazeneuve, Jean Communication de masse et mutations culturalles, »Cahiers internationaux de sociologie«, јануар-јун 1969.

Debord, Guy. Comments on the Society of the Spectacle, Verso, New York,1988. Debord, Guy Society of the Spectacle, Zone Books, New York, 1994.

Foucault, Michel Surveiller et punir: Naissance de la prison, Gallimard, Paris, 1975.

Јанићијевић, Јасна. Комуникаиија и кулимура. Издавачка књижара Зорана Стојановића, Сремски Карловци, 2000.

Јанићијевић, Јасна. Меgиоірафија, необјављено дело.

Jappe, Anselm. A Guide to Guy Debord s Concept of the Spectacle. Treaso Press, London, 1999

Kellner, Douglas. Media Spectacle. Routlegde, New York, 2003

Келнер, Даглас. Меgијска кулииура. Клио, Београд,2004.

Foucault, Michel. Surveiller et punir:Naissance de la prison. Gallimard, Paris, 1975.

Маклуан, Маршал. Познавање ойшӣила-човекових йрояужет̄ака. Просвета, Београд, 1971.

Саид, Едвард. Кулимура и имиееријализам. Београдски круг, Београд, 2002.

Вуксановић, Дивна. Филозофија меgија. Чигоја, Београд,2008. 
Ratko Božović

\section{Summary}

\section{CRISIS OF MEDIA COMMUNICATION:}

\section{On the track of the Manuscript Mediography by Jasna Janićijević}

Following the track of an unpublished manuscript named Mediography, in which Jasna Janićijević identified the functions and contents of mass media, their thematic limitations, the narcotic like dysfunction, reproductivity, tendentiousness, anti/intellectualism, as well as conformity, the author of this text points out the fatal (damaging) effects of contemporary crisis regarding media communication. Keeping Jasna Janićijević's ideas in mind, the writer particularly analyses the significance of education for media sphere, where freedom, responsibility, control as well as, self control, would be permanent constants.

Key words: culture, media culture, communication, crisis, education, viewer, review 